Bello-Pintado, A. and Bianchi, C. (2019), "Consequences of open innovation: effects on skill-driven recruitment", Journal of Knowledge Management, Vol. 24 No. 2, pp. 258278. https://doi.org/10.1108/JKM-08-2019-0437

\title{
Consequences of open innovation: effects on skill-driven
}

\section{recruitment}

\section{Abstract \\ Purpose}

This paper focuses on the human side of inbound open innovation by analysing the effects that the adoption of different knowledge search strategies for innovation has on new recruitment needs.

\section{Design/methodology/approach}

Building on several theoretical perspectives, the study proposes three hypotheses regarding the relationship between openness and the need to recruit people with high technical and social skills. Using a pooled panel data from the Uruguayan Innovation Survey between 2004 and 2012 we identify open strategies followed by the firm.

\section{Findings}

The estimation results using pooled panel data and panel data techniques confirm that the adoption of open search strategies for innovation demands the recruitment of new employees with higher technical and social skills. Technical skills are more likely to be demanded than social skills. The effects observed are higher when the firms use intensively knowledge and information sources. 


\section{Originality/Value}

This paper revisits the analysis of specific knowledge search strategies at the firm level. In doing so, the study looks for the effects of specific strategies combining different knowledge sources and considers different levels of use of external KISs, from narrow to wide. While other studies have analysed the human factor as a determinant of the success of openness for innovation, this paper re-examines the direction of this relationship. Finally, the study contributes with evidence from a Latin American country, where these topics have received less attention.

Keywords: Open innovation, social skills, technical skills, recruitment

Paper type: Research paper

\section{Introduction}

In the last decade, researchers have highlighted the role of open innovation as a key driver of innovation performance (Laursen and Salter, 2006; Bogers et al., 2018). Hence, infrastructures and antecedents for firms' effective and efficient innovation openness have received considerable attention in the literature (Leiponen and Helfat, 2010; de Araújo Burcharth et al., 2014).

Studies in the field have observed greater complexity of complementary knowledge search strategies aimed at enhancing innovation performance (Grimpe and Sofka, 2016), increasing both the search breadth (number of sources) and the search depth (intensity of use) of knowledge and information sources (KISs) (Laursen and Salter, 2006). In this context, the "human side" of open innovation has increasingly been recognized as a determinant of the capture and integration of both external and internal sources of knowledge (Bogers et al., 2018; Criscuolo et al., 2018). New sets of technical 
and social skills and backgrounds are required from the firm's workforce (Petroni et al., 2012; Salge et al., 2013), among other things to improve searching (Dahlander et al., 2016) and to establish collaborative communication, encouraging the development of relationships with external actors (Pemartín et al., 2018).

From Cohen and Levinthal (1989), it is known that innovation success depends on the ability to acquire, absorb and exploit new knowledge. However, interorganizational knowledge flows do not materialize automatically, and firms need to acquire or develop new skills to explore and exploit new external sources of information and knowledge (Eisenhardt and Martin, 2000; Vanhaverbeke et al., 2008). In this sense, this study focuses on the organizational consequences of adopting different open innovation strategies, paying special attention to the new need to recruit people with high technical and social skills to manage complex combinations of KISs. On this line, Ter Wal et al. (2017) stated that, in the long run, the relationship between skills and innovation strategies is circular: new skills are necessary to innovate and innovation requires new skills. In addition, there has been growing interest in the "dark side" of open innovation, attending to the costs of and barriers to adopting open innovation strategies (Katila and Ahuja, 2002; Villena et al., 2011; Laursen and Salter, 2014; Greco et al. 2019). However, until now, the evidence concerning the relationship between open strategies and skill-driven recruitment of people has been very limited (Stanko et al., 2017).

This paper elaborates a theoretical reasoning to hypothesize how the use of different KISs affect firms' recruitment needs. The process of open innovation is complex and dynamic, and no isolated theoretical perspective is able to explain fully the entirety of its organizational effects (Remneland-Wikhamn and Knights, 2012). As a result, 
different approaches need to be considered to understand the organizational effects of adopting different openness strategies (Bogers, 2012; Greco et al., 2019).

According to the literature on open innovation and strategic human resource management (HRM), the association between openness and new demands for recruiting people is controversial (Vanhaverbeke et al., 2014). On the one hand, adopting open innovation strategies enables firms to develop effective competitive strategies without requiring numerous and varied, or even any, employees working in research and innovation (Chesbrough, 2006). However, firms that engage in open innovation may need to incorporate new technical and social skills to improve their searching, communication and adaptation to team working (Hillebrand and Biemans, 2004; du Chatenier et al., 2010; Salge et al., 2013). Companies that are involved in openness strategies may increasingly demand employees with competences and abilities to manage both inside-out and outsidein open innovation flows (Chiaroni et al., 2011; Clausen, 2013; West and Bogers, 2014). Through recruitment, firms can access unique ideas and insights (Bogers et al., 2018) as well as technical skills and backgrounds, improving the search for, selection and assimilation of new information and knowledge from different actors for both inbound and outbound open innovation (Lichtenthaler and Lichtenthaler, 2009; Clausen, 2013; West et al., 2014).

In sum, this paper aims to contribute to the current literature on the "human side" of open innovation by answering the following questions:

- Are open innovation strategies associated with new recruitment needs for technical and social skills?

- Does different open innovation strategies explain different needs of skillsdriven recruitment? 
Empirically, the hypotheses are tested using pooled panel data of 1,466 firms in the manufacturing and service sectors using the Uruguayan Community Innovation Survey covering the 2006-2012 period.

This paper contributes to the literature on the human side of open innovation in several ways. Firstly, it revisits the analysis of specific knowledge search strategies at the firm level. Rather than just following the studies on the breadth and depth of openness, the study also looks for the effects of specific strategies combining different sources (Backfisch, 2014; Criscuolo et al., 2018). As an extension, the study considers different levels of use of external KISs, from narrow to wide. Second, in contrast to other studies that have analysed the human factor as a determinant of the success of openness strategies for innovation (Lippitz et al., 2017; Bogers et al., 2018), this paper re-examines the direction of this relationship, considering that openness in innovation may determine the need for more skilled workers. Hence, it approaches the consequences and challenges of open innovation. Finally, the study is undertaken in a Latin American country. While there has been a call for open innovation research in non-Western settings (Cheng and Huizingh, 2014), very few studies have analysed aspects related to open innovation in Latin America (Chaston and Scott, 2012; Arruda et al., 2013). Most of those have been case studies (Rodrigues et al., 2010; Ades et al., 2013) or have analysed the productive strategies in specific economic activities (Brenes et al., 2014; Ramos et al., 2018) rather than studying the open innovation phenomenon on an economy-wide basis. While this is a limitation when generalizing the empirical findings of this study to other regions, the empirical evidence of this study is a contribution in itself.

\section{Theoretical Framework}


The relationship between workforce skills and innovation has received the attention of the literature on different analytical levels (Freel, 2005; Tether et al., 2005; Deming, 2017). Workforce skills for innovation are a combination of education, talent and experience (Thether et al., 2005). Different types of skills are critical to the success of innovation strategies (Ter Wal et al., 2017). Sousa and Rocha (2019) identified three critical skills for innovation in the digital IT industry: innovation, leadership and management, that included technical knowledge and social skills linked with communication, networking or talent management. In addition, Ter Wal et al. (2017) stressed the dynamics between skills and innovation, suggesting that new skills are required to assimilate new external knowledge and remain innovative.

The paper elaborates on how different search strategies affect the demand for new technical and social skills at the firm level. It defines technical skills as those abilities associated with a formal qualification with a technical or scientific background. These are the result of formal training and experience expressed as the technical capacity to solve relevant problems for the firm (Freel, 2005; Deming and Kahn, 2018). On the other hand, social skills are defined as cooperation and communication abilities, which are potentially related to formal education but are mainly based on personal features and grounded by experience in different contexts (Freel, 2005; Deming, 2017).

\subsection{Open Innovation and New Recruitment Needs: Hypothesis Statements.}

The degree of openness is a strategic decision resulting from the firm's balance between costs and benefits of more or less openness (Felin and Zenger, 2014). The transaction cost theory (TCT) states that firms begin to organize their production processes internally when the transaction costs of coordinating production using market mechanisms is greater than doing so within the firm (Williamson, 1981). The open 
innovation approach is closely related to the TCT with respect to the way in which firms set their boundaries and the extent to which knowledge flows through firm boundaries (Chesbrough, 2003). However, the perspective of TCT has been somewhat neglected in the literature of open innovation along with the study of the interactions of firms with external sources of KISs (Greco et al., 2019). The success of open strategies depends on the associated transaction costs of searching and controlling in a process that is interactive in nature (Faems et al. 2010) and in which the contact between different actors is more or less formalized (Baldwin and Von Hippel, 2011). The existence of hidden costs of communication, control, evaluating information and bargaining associated with innovation openness (Stuermer et al., 2009) can limit the effectiveness of the opening innovation process (Laursen and Salter, 2014; West and Bogers, 2014). Hence, technical skills and the background of the firm's workforce are critical to the cost of searching for valuable knowledge (Köhler et al., 2012) and for the transaction cost when firms manage a high variety of external sources (Laursen and Salter, 2014).

In addition, the transaction cost of a firm's openness strategy will depend on the cognitive distance between the firm and each external KISs (Nooteboom et al., 2007; Criscuolo et al., 2018). Integrating cognitively distant actors may offer new knowledge and innovativeness, but may increase the cost relating to searching, exploring new markets and coordinating different sources (Lichtenthaler and Lichtenthaler, 2010; Criscuolo et al., 2018). With this regard, it has been demonstrated that combining a wide number of sources of knowledge, including cognitively distant actors, could be detrimental to firm success (Das and Teng, 2000). Asimakopoulos et al. (2019) confirmed an inverted U-shaped relationship between innovation outputs and openness, suggesting an increasing transaction cost when adopting more complex and integrative strategies (Laursen and Salter, 2014). As a result, adopting integrative strategies involving 
cognitively distant actors may demand new skills (social and technical) to manage the opening process in the best way.

An important element to consider when assessing the effects of expanding the number of KISs is the absorptive capacity of firms. According to the absorptive capacity view (Cohen and Levinthal, 1989), the effectiveness of exploration and exploitation of new KISs require a set of skills to transfer knowledge and to assimilate and modify this imported knowledge (Zahra and George, 2002). The adoption of open innovation processes can be developed and supported only if companies possess their own competences to assimilate external knowledge (Dahlander and Gann, 2010; Clausen, 2013). In this context, human resources become a strategically critical asset of organizations (Grant, 1996) for developing open innovation strategies (Gomez-Mejía et al., 2004; Herstad et al., 2015), which in turn may increase the need to recruit highly qualified staff to capture and manage new information and knowledge (Fawcett et al., 2012; Criscuolo et al., 2018). If not, firms may not be able to follow the open approach to innovation (Clausen, 2013).

Based on this reasoning, we propose the following hypothesis:

H1. The new recruitment needs for both technical and social skills increase with the number of KISs combined in open innovation strategies.

Regarding the effects of the intensity of the use of KISs on new recruitment needs, researchers have related the "depth" of open innovation strategies with higher levels of absorptive capacities (Laursen and Salter, 2006). Absorptive capacity is related to prior skills and knowledge, and is cumulative since its development in the present will permit its more efficient accumulation in the future (Vega-Jurado et al., 2008). It can be 
developed internally or acquired, for instance by hiring new personnel or contracting consulting services, but, in general, both happen simultaneously (Christensen, 2006).

The depth of openness is determinant to sustain a pattern of interaction with external agents over time, allowing building shared meanings and trust (Ferreras-Méndez et al., 2015). However, developing one's own skills and capabilities to implement open innovation strategies implies time and effort, and individuals have limited amounts of time and attention available to perform their daily tasks (Ocasio, 1997). Therefore, new recruitment of external sources can be a determinant of the avoidance of employees working deeply on too broad a range of activities related to searching for and assimilating KISs, as they may struggle to allocate their time effectively across these tasks (Dahlander et al., 2016). Thus, the recruitment of workers with higher technical and social skills will contribute to enhancing the capacity of a firm to interpret and transmit acquired knowledge within the organization (Bishop et al., 2011). Ebers and Maurer (2014) stated that individuals will only be able to advance in developing strong and trusted external or internal ties, if they possess the appropriate social skills, which are determinant to establish specific norms for in-depth cooperation (Hillebrand and Biemans, 2003). We propose the following hypothesis:

H2. The new recruitment needs for both technical and social skills increase with the intensity of use of KISs combined in open innovation strategies.

The demands for technical and social skills associated with open innovation strategies depend on the company's opening stage, from unfreezing, when external KISs 
are rather marginal, to institutionalization, when innovators rely heavily on external sources (Chiaroni et al., 2011).

Assessing the depth of firms' contents from different sources, especially in companies that institutionalize open innovation, not only demands technical capabilities but also social skills to manage strategies integrating broad and varied knowledge from close and distant sources (Criscuolo et al., 2018).

As a result, establishing an open innovation strategy usually involves looking for new technical skills and capabilities (Hall and Bagchi-Sen, 2007); however, employees on inter-organizational boundaries should be able to exchange information in an effective manner between organizational groups, which demands a minimum of technical skills (Ancona and Caldwell, 1992). This suggests the existence of differences in the relevance of different skills (technical and social) according to the openness strategy. In this sense, Du Chatenier et al. (2010) identified three main tasks required for professionals involved in work teams to develop open and integrative innovation projects effectively: managing inter-organizational innovation, managing the overall innovation process and creating knowledge collaboratively. According to this study, brokering solutions involving high technical skills is the most important competence for professionals working in open innovation projects integrating KISs. This study also highlighted that being socially competent is important to manage diverse KISs. Aligned with this, Petroni et al., (2012) stated that high technical-scientific skills of employees and a strong technical knowledge base are determinants of the adoption of advanced open innovation strategies that combine broad and varied knowledge from different sources.

Regarding social skills, it has also been stated that implementing open innovation strategies will demand specific communication (Hillebrand and Biemans, 2004) and teamwork skills (Maltz and Kohli, 2000). On this line, Jansen et al. (2005) 
stated that exploring and assimilating KISs require both coordination and socialization capabilities. Relatedly, Lindegaard and Kawasaki (2010) showed that social skills based on attitudes and interpersonal abilities are a determinant of being embedded in a dense network of interactions (Laursen and Salter, 2006).

Based on this reasoning, we propose the following hypothesis:

H3. Technical skills are likely to be demanded for all open innovation strategies (from low to high use of KISs), while social skills are likely to be demanded for high and intensive use of KISs.

\section{Methodology}

\subsection{Data}

The data set used in this study was built by aggregating three waves of the Uruguayan Innovation Survey (UIS), which cover the period between 2006 and 2012. The surveys contain cross-sectional data on Uruguayan firms, and they are representative of manufacturing and 8 Uruguayan service sectors, considering firms with 5 or more employees. The sampling method combines random sampling of firms with fewer than 50 employees with the compulsory inclusion of larger firms. The authors were able to build panel data due to the identifiers provided by the National Agency of Research and Innovation of Uruguay.

Using innovation survey data raises some methodological issues and presents pros and cons regarding other sources of information about innovation at the firm level. Some criticism of innovation surveys points out that the data are self-reported, which may lead to unobservable biases (Mairesse and Mohnen, 2010). However, self-reported data allow researchers to address some specific information that cannot be captured using only 
administrative records. For example, the number and type of KISs used by a firm is not available in any records except for case studies. Moreover, innovation surveys based on the Oslo Manual (Organisation for Economic Cooperation and Development (OECD), 2005) guidelines are explicitly oriented towards capturing the actions that the subject (firm) conducts to innovate. Therefore, innovation surveys offer unique information that allows researchers to analyse innovation strategies and capacities to use, manage and search for external knowledge (Criscuolo et al., 2018).

The data set contains 5,511 observations of 2,782 firms. Of the observations, $40 \%$ represent firms with innovation activity in that period. Due to the UIS questionnaire only collecting KISs' use information for innovative firms, the final sample includes all the firms that declared that they had conducted at least 1 innovation activity in the period. Therefore, we work with an unbalanced panel data set of 2,205 observations from 1,466 firms (Table 1).

\section{Table 1 about here}

\subsection{Dependent Variables}

The UIS specifically asks whether the demand for technical skills (qualified employees in any particular area of knowledge) and social skills (abilities to cooperate and adaptability for teamwork skills) increased, stayed the same or decreased because of the innovation strategy developed (see Appendix, Table A1).

We consider the demand for qualifications as technical skills; while to capture social skills we build an indicator that includes both cooperation, communication and adaptation skills. Most of the firms in the sample maintained or increased their levels of demand for new skills in the recruitment process of new employees (Table 2). The percentage of firms that decreased their need for new recruitment was extremely low, and therefore they were not considered for the estimations. 


\section{Table 2 about here}

\subsection{Explanatory Variables}

The study operationalized the concept of innovation openness, its key explanatory variable, through combinations of external KISs, defined as knowledge search strategies. Hence, the number and variety of the external KISs that a firm uses in the innovation process express the firm's degree of openness. The paper considers all the strategies that result from combinations of five sources of information: (1) suppliers, (2) customers, (3) competitors, (4) conferences, magazines and fairs and (5) universities and technological centres. ${ }^{1}$ These sources have been used in other empirical studies (Laursen and Salter, 2006; Sofka and Grimpe, 2010; Backfisch, 2014; Criscuolo et al., 2018) and are comprehensive of a wide range of institutions and linkages that comprise the national innovation system.

The responses to the survey are converted from a four-point scale on the relevance of each knowledge and information source (where 1 is "high", 2 "medium", 3 "low" and 4 "irrelevant") into binary variables that take the value of 1 if the relevance of the source is low, medium and high and 0 if it is irrelevant. The variable breadth is constructed as combinations of all these sources. For depth strategies, following Laursen and Salter (2006), we combine the binary variables that take a value of 1 if the relevance of the source is high and 0 otherwise (see Table 3 ).

This means that, in the case of "low intensity", a search strategy called "suppliers" captures those firms that rate the use of suppliers as a source of innovation with low, medium or high importance (taking the value 1) and do not use any other sources to a low, medium or high extent. In the case of "high intensity", the same strategy

\footnotetext{
${ }^{1}$ For universities and research centers, the variable is created using two different sources: universities or research centers and consultants. Conferences, magazines and fairs, is constructed similarly. Reducing the number of sources facilitates the analysis of different combinations of sources. See appendix, Table A2.
} 
captures those firms that rate the use of suppliers as a source of innovation with high importance (taking the value 1) and do not use any other sources to a great extent.

To analyse the effects of different openness strategies, combinations of the five different KISs produce 33 knowledge search strategies ranging from not using any external sources of information to using all 5 sources. The study maintains the criteria of breadth and depth to build the different strategies according to the intensity of the use of the sources (Table 3 displays the frequency of each strategy). At the end of the table, the openness strategies are ranked from 0 to 5 according to the use of sources. It can be observed that, for the "low intensity" scenario, the most frequent combination is all sources combined ( $41 \%$ of firms), while, in the "high intensity" scenario, it can be observed that the most frequent strategies are "no sources" $(32.88 \%)$ or "one source" $(31.75 \%$ of the firms).

\section{Table 3 about here}

\subsection{Control variables}

Table 4 presents a set of control variables used in the econometric models. Most of these variables refer to firms' characteristics, which have been widely tested as determinants of firms' innovation behaviour (Cohen, 2010). Moreover, to control for the presence of high-skilled human resources in the firms, the study includes a dummy that takes the value of one if the firm has at least one employee who has completed university education in its workforce. There is evidence for Uruguay that the presence of at least one professional in the firm positively affects the probability that the firm will engage in collaborative innovation activities (Bianchi et al., 2011). 


\section{Results}

Since the dependent variables contain two categories, the methodology used to estimate the impact of adopting open innovation strategies on the changes in recruitment needs is a multivariate logistic regression model. We run logit regression models for the pooled dataset, including fixed effects by sector and year. The estimation results can be observed in Tables 5 and 6. Table 5 reports the regression results of the breadth and depth indicators of innovation openness regarding the likelihood of increasing recruitment needs in technical skills and social skills. The first two columns show the baseline model estimation. Most of the control variables have the theoretically expected sign. Some variables, export share or being part of a group, are not statistically significant. It is important to note that the observed effect of these variables remains practically unchanged in all the estimates.

Specifically, it can be observed that the size of the firm is positively associated with an increase in the recruitment need for new employees with technical skills, while the demand for social skills is not significant. It is also apparent that firms companies that declared that they faced some limitations in undertaking innovation activities because they did not have skilled workers increased their recruitment needs for new employees with both technical and social skills. Finally, the use of internal sources as a source of information and knowledge for innovation required the recruitment of employees with more technical and social skills. In general, similar results have been observed in the literature on open innovation (Salter and Laursen, 2006; Criscuolo et al., 2018).

\section{Table 5 about here}


The estimations for the breadth and depth openness indicators are positive and statistically significant in explaining the likelihood of an increase in the recruitment needs for employees with higher technical skills and social skills (Table 5, columns 3 and 4). Thus, aligned with hypothesis 1 , it can be observed that both human capital dimensions considered increase with the number of sources of information and knowledge (breadth) scanned by firms (technical skills: $B=0.110, \mathrm{p}<0.01$; social skills: $B=0.0757, \mathrm{p}<0.10$ ). Moreover, the estimations show that the intensity of the use of external sources (depth) increase the likelihood of increasing the recruitment of new employees with technical skills $(B=0.182, \mathrm{p}<0.01)$ and social skills $(B=0.137, \mathrm{p}<0.01)$, confirming the hypothesis 2. Table 6 reports the results of the logistic regression on the likelihood of increasing the recruitment needs of technical and social skills regarding the adoption of different open innovation strategies (combinations of KISs), distinguished by the level of intensity in the use of sources. This allows us to approach hypotheses 1 and 2 from a different perspective. A quick view of the estimation allows the extraction of three main results that reinforce the findings of breadth and depth (Table 5). First, the number of open innovation strategies that demand new employees with higher technical skills is larger than the number affecting the new recruitment of employees with higher social skills (Table 6). Second, the number of combinations that are positively associated with the likelihood of increasing the recruitment needs for people with more technical and social skills is greater when the intensity of use of external sources for innovation is high than when this intensity is low (Table 6, comparing columns 1 with 3 and 2 with 4). Third, to the extent that combinations involve a greater number of actors, the demand for new skills also increases, mostly when the intensity of the use of sources is high.

With regard to technical skills, it can be observed that the number of openness strategies that significantly affect the likelihood of new recruitment increases with the 
number of sources implied. For instance, when considering low intensity of the use of sources (column 1), no strategies, including only one source, increase the recruitment needs compared with companies that are not involved in open innovation. Similarly, only two strategies, including two sources, increase the recruitment needs of more technically qualified employees (universities and customers: $\mathrm{B}=0.780, \mathrm{p}<0.10$; universities and competitors: $\mathrm{B}=1.659, \mathrm{P}<0.10)$. In addition, it can be observed that the rest of the strategies involving more actors (three, four or all sources) are more likely to demand new employees with high technical skills. These combinations of sources usually include both close and distant actors.

\section{Table 6 about here}

Hypothesis 2 stated the likelihood that the recruitment need for both technical and social skills is more likely to increase with the intensity of use of different KISs in open innovation strategies. The estimation results in Table 6 show that some openness strategies are more likely to demand new technical and social skills when increasing the intensity in the use of different sources. This effect is observed in the case of both strategies involving small and large numbers of sources. In the case of technical skills, it can be observed that firms that only use universities and research centres ("universities") intensively as KIS demand new technical skills $(\mathrm{B}=0.519, \mathrm{p}<0.01)$, while, for social skills, the same strategy is not significant. It is remarkable that, considering high intensity use of KIS, all strategies that demand the recruitment of new technical skills involve the participation of universities. In addition, some combinations involving two sources other than universities, also increase the need for new technical skills when increasing the intensity of the use of the sources (suppliers and customers: $B=0.382, p<0.10$; suppliers and fairs: $\mathrm{B}=0.730, \mathrm{p}<0.05$; customers and fairs: $\mathrm{B}=0.543, \mathrm{p}<0.10$ ). 
In the case of social skills, an increase in the recruitment needs is observed in strategies integrating two and three sources. It can also be stated that this effect is observed in strategies involving cognitively close and distant sources (e.g. suppliers and customers: $\mathrm{B}=0.590, \mathrm{p}<0.05$; universities and customers: $\mathrm{B}=0.990 ; \mathrm{p}<0.01$; suppliers, universities and customers: $\mathrm{B}=0.790, \mathrm{p}<0.05$; suppliers, competitors and fairs: $\mathrm{B}=1.425$, $\mathrm{p}<0.05$ ). In addition, when comparing low versus high intensity use of sources, social skills are more likely to be demanded when strategies involve four sources of information and knowledge. Table 7 shows that the likelihood of increasing the recruitment of new employees with higher social skills is around $20-30 \%$ compared with firms that are not involved in open innovation when the sources are used intensively. However, we do not have a theoretical explanation for the negative sign of the strategy: "Universities only" (Table 6, column 2).

Finally, hypothesis 3 stated that technical skills are likely to be demanded for lowintensity and high-intensity use of sources while social skills are likely to be demanded only for highly intensive use of sources. The estimation results show that technical skills are more likely to be demanded than social skills in both scenarios considered. It can be observed that some strategies including two or three sources increasingly demand technical skills in the scenario of the narrow use of sources, while, in this context, any strategy increases the demand for social skills. However, in the scenario of deep use of sources, both technical and social skills are demanded. The marginal effects of statistically significant combinations are summarized in Table 7 . It can be observed that the strategy combining two distant actors (universities and competitors) increases the likelihood of recruiting new employees with higher technical skills by $40.9 \%$. The combinations that increase the likelihood of recruitment of new employees with higher 
technical and social skills to a greater extent include a high number of sources or in some cases a small number of distant sources.

\section{Table 7 about here}

It can be observed that the intensity of use is a determinant compared with the number of KISs to explain the differences between technical and social skills. For instance, any strategy of open innovation is statistically significant in explaining an increase in the likelihood of recruiting people with higher social skills when the use of sources is narrow (Table 6, column 2), with the exception of the negative sign of the strategy "universities only". Moreover, when the intensity of the use of sources is high (Table 6, columns 3 and 4), it can be observed that the number of statistically significant combinations increases for both technical and social skills. In sum, aligned with Noteboom (2007), social skills as well as technical skills are important to integrate cognitively distant sources of knowledge and to combine near and distant sources. Thus, hypothesis 3 can be confirmed.

Overall, the estimations confirm that integrative strategies increase the demand for both technical and social skills. Looking for the individual effects of different combinations of sources, the study investigated whether the intensity of the use of different sources in openness strategies moderates the need for new employees to be recruited. When openness strategies include narrow intensity in the use of sources, it can be observed that only technical skills are demanded; however, when considering firms that only use different sources intensively, it is apparent that both technical and social skills are demanded.

We test the robustness of the estimates obtained through logit models. The coefficients are similar when estimated using probit or ordinary least squares (OLS) 
models. We also estimate two different tobit models, one left-censored and the other rightcensored, to obtain greater accuracy regarding specific recruitment patterns. The coefficients are similar to those obtained using ordered logit models or OLS.

Moreover, in order to control potential endogeneity bias, we use a reduced panel dataset that include only those firms that have been surveyed at least two times $(1,282$ observations from 543 firms). Hence, we instrumented the independent variables (breadth and depth) using their measures one in lagged period (breadth $t_{t-1}$ and depht $\left.t_{t-1}\right)$. The estimates from IVProbit models resulted mostly in no significe and the Wald test of the exogeneity of the instrumented variables was not significant. Therefore, we do not observe endogeneity bias, and the original logit binomial model offers the most consistent estimates.

\section{Discussion and Conclusions}

The benefits of innovation openness have been widely discussed in the literature on the management and economics of innovation. Researchers have shown the benefits of combining different openness strategies; complex and balanced combinations of knowledge sources provide opportunities for enhanced innovation performance in terms of product and process innovation (Backfisch, 2014; Criscuolo et al., 2018). This study deals with the effects of innovation openness, specifically analysing the changes in the recruitment of people associated with new demands for technical skills and social skills. In doing so, the paper contributes to the knowledge on the human aspect of innovation, often little considered in the literature on open innovation (Bogers et al., 2018).

Using several theories and the most recent empirical evidence in this field, the study tried to improve the understanding of the consequences of open innovation, focusing on the effects that adopting different openness strategies have on the need to 
recruit people with higher technical and social skills. The estimations show that the adoption of broad open innovation strategies demands employees with more technical and social skills. However, it was observed that technical skills are more likely to be demanded than social skills when firms establish intensive searching strategies with different actors in relation to those firms that do not implement open strategies. Finally, the study looked for the effects on recruitment needs of specific strategies, from simple strategies including only one source to more integrative strategies including both close and distant sources. It found that technical skills are demanded in a large number of combinations (integrative) compared with social skills, which are more likely to be required only when the intensity in the use of sources is high.

For technical skills, it is important to point out that, although the number of strategies is statistically significantly greater when the intensity of the use of the sources is also greater, it was observed that the more frequent combinations include only a small number of actors (two sources). This would indicate that companies focusing intensively on the use of sources are not able (technically) to incorporate a greater number of sources. Regarding social skills, open strategies that are more likely to demand new employees with higher social abilities combine more sources. Thus, the effect of increasing the intensity of the use of sources and the number of sources combined is rather more important for social skills than for technical skills.

In sum, comparing technical and social skills, the study confirms that technical skills are more likely to be demanded than social skills according to different search strategies (combinations of sources), from narrow to deep search combinations. Some "simple combinations" integrating one or two sources appear to be associated with new recruitment needs for technical skills and social skills. However, in accordance with the literature, these simple strategies do not allow firms to achieve higher innovation 
performance (Villena et al., 2011; Criscuolo et al., 2018) and make firms face the challenge of recruiting highly qualified employees (Petroni et al., 2012).

The results of this study have implications for the academia, policy makers and practitioners, and for employees.

Regarding the academia, the results are consistent with the expectations from the literature reviewed but create some controversy related to the origins of the adoption of open innovation strategies. According to Chesbrough (2006), many firms adopt open strategies for innovation as a response to insufficient suitable internal resources to adopt a close strategy or even because of the inability to recruit knowledgeable people associated with financial limitations, small size of firms or low business attractiveness. However, the study demonstrates that achieving high innovation performance by capturing new ideas, valuable information and knowledge from different sources is associated with new recruitment of people with high technical and social skills. Overall, the paper demonstrates that firms that increasingly adopt openness for innovation and engage with external sources face the need to recruit employees with the ability to understand and absorb knowledge in collaborative environments. This confirms that open innovation processes occur in a very dynamic way, challenging the company to be able to absorb information and knowledge for both outside-in and inside-out flows. The literature has shown that this requires the internal development of capabilities to absorb and exploit new knowledge. However, our study demonstrates that this process must be complemented with the incorporation of new workers with higher technical and social skills, which are necessary to implement various strategies, mainly those that integrate a large number of KISs.

Another implication for academia is associated with the specific difficulties of training and transferring soft skills (intrapersonal and interpersonal) rather than hard skills 
(technical). This lack of soft-skill transfer results in an extremely costly waste of time, energy and money for firms (Laker and Powell, 2011), and therefore, academia should improve soft-skill training in higher education and in more elementary courses (Ngang et al., 2015).

For practitioners, this study demonstrates that adopting and maintaining open innovation strategies is a challenge for firms, since it requires new technical and social skills, to intensify open innovation strategies and advance in implementing more open and integrative strategies. Hence, while enhanced innovation performance has been associated with the adoption of complex and integrative combinations of sources, achieving high performance will demand employees with higher technical and social skills. This study highlights the need to attract and retain staff with high qualifications and abilities to adapt and work in groups, which is especially challenging in less developed contexts. In this sense, implementing human resource practices such as team rewards or extensive selection have been demonstrated to be useful to identify, attract and retain high-skilled workers (Laursen and Foss, 2014). In addition, improving the knowledge base allows firms to intensify their collaborations in networks, which may increase specific knowledge and amplify the possibilities to contact and recruit new employees (Podmetina et al., 2013).

For policy-makers, the main contribution of this study is that when considering policies promoting open innovation activities, they must also consider that firms should be able to improve their human capital as a response to an incremental process of open innovation, which usually integrates close and distant sources of information and knowledge. Therefore, open innovation actions should be complemented with a recruitment policy, which, in the case of SMEs, should include public subsidies for hiring and training highly qualified workers. The study shows that technical skills (in any area 
of knowledge) are usually demanded more, regardless of the intensity of the use of sources for openness strategies. Technical skills are easily observable. However, social skills that appear to be demanded in more integrative strategies with a high use of sources are more difficult to identify but easier to train (Petroni et al., 2012).

In addition, our study contributes to the open debate on job destruction and technology change (e.g. Frey and Osborne, 2017; Aghion et al., 2019). In Uruguay, as in many countries facing the current ICT diffusion wave based on robotics and automation, policy-makers, unions and firms have been discussing the potential impact of the technical change and innovation in employment, productivity and business models. In the specific case of Uruguay, this issue is of critical concern among the "mega trends" identified by the Uruguayan National Development Strategy (OPP, 2019), as a critical challenge for the country. This paper offers relevant implications to inform this discussion beyond the alternatives to mitigate an apparent inevitable job destruction process by offering evidence of potential job creation related to innovation activities and innovation strategies beyond the incorporation of ICT. In addition, while recruiting highly skilled workers is a challenge for firms, it can also be an opportunity to attract and retain highskilled people to work on broad and integrative innovation projects, increasing the firms' human capital and supporting their competitive advantage (Laursen and Salter, 2014).

For employees, the study highlights the importance of social skills and competencies (such as working groups or communication) to manage open innovation strategies. They should be trained in these aspects and incorporate them into the technical skills needed to work in innovation contexts. These traits will be valued and desired more by firms.

The paper presents a number of limitations. First, the results of this study must be read within the context of a developing country. Uruguay is a developing country with a 
challenging shortage of qualified human resources (Bello-Pintado and Barcés-Galdeano, 2017). In this sense, firms have typically faced such constraints, which can limit the internal development of capabilities associated with the innovation process. Furthermore, it may be desirable to complement the debate on the human capital consequences of open innovation by considering in the future the impact of internal training practices as determinant for the absorptive capacity of firms. Recent studies suggest that training affects performance, through the effect on developing exploitation capabilities for innovation (Hernández-Perlines et al., 2015). Second, this study only considers search strategies rather than search and collaboration strategies. Further research should address a broader measurement of the degree of openness that considers the external knowledge sources and the linkages with other agents as well as formal collaboration agreements in which firms are engaged to innovate. In addition, data available should allow to identify between inside-out and outside-in flows in order to identify the consequences and determinants of each strategy (Michelino et al., 2014). Moreover, it is necessary to integrate the study of complementarities (Belderbos et al., 2006) - both between different external sources and between internal and external sources - and the concept of strategies as knowledge source combinations (Backfisch, 2014). This may contribute to improving the understanding of the specific combinations of sources, which depend on the internal and the external context of the firm (Lazzarotti et al., 2015). Finally, the econometric strategy is based on the estimation of correlations; hence, the results have no causal claims. Due to low number of waves of the UIS that contain information about the recruitment of skills, the use of fixed-effect models or other estimate methods to control endogeneity bias are still not available. 


\section{Acknowledgements}

The authors would like to thank Felipe Berrutti and Pablo Blanchard for valuable research assistantship. They acknowledge the collaboration of the Agencia Nacional de Investigación e Innovación, Uruguay, which provided access to UIS microdata. This study has been conducted within the frameworks of the following projects: CSIC, Uruguay, No. 335/2016 and Department of Economy, Industry and Competition, Spain, No. ECO2017-86305-C4-4-R.

\section{References}

Ades, C., Figlioli, A., Sbragia, R., Porto, G., Ary Plonski, G. and Celadon, K. (2013), "Implementing open innovation: the case of Natura, IBM and Siemens", Journal of Technology Management \& Innovation, Vol. 8, pp. 12-25.

Aghion, P., Bergeaud, A., Boppart, T., Klenow, P. J. and Li, H. (2019), "Missing growth from creative destruction", American Economic Review, Vol. 109 No. 8, pp. 27952822 .

Ancona, D. and Caldwell, D. (1992), "Bridging the boundary: external activity and performance in organizational teams", Administrative Science Quarterly, pp. 634 665.

Arruda, C., Rossi, A., Mendes, G. and Ferreira, P. (2013), "The influence of external search strategies on the innovative performance of Brazilian firms", Journal on Innovation and Sustainability. RISUS, Vol. 4 No. 1, pp. 43-59.

Asimakopoulos, G., Revilla, A., and Slavova, K. (2019). External Knowledge Sourcing and Firm Innovation Efficiency. British Journal of Management. DOI: $\underline{10.1111 / 1467-8551.12367}$

Backfisch, M. (2014), "Search Balance and Product and Process Innovations", Joint Discussion Paper Series in Economics, No. 61-2014.

Baldwin, C. and Von Hippel, E. (2011), "Modeling a paradigm shift: from producer innovation to user and open collaborative innovation", Organization Science, Vol. 22 No. 6, pp. 1399-1417.

Belderbos, R., Carree, M. and Lokshin, B. (2006), "Complementarity in R\&D cooperation strategies", Review of Industrial Organization, Vol. 28 No. 4, pp. 401426.

Bello-Pintado, A. and Garcés-Galdeano, L. (2017), "Bundles of HRM practices in family and non-family firms: the impact on enhancing performance", The International Journal of Human Resource Management, pp. 1-22.

Bianchi, C., Gras, N. and Sutz, J. (2011), "Make, buy and cooperate in innovation: evidence from Uruguayan manufacturing surveys and other innovation studies", in CEPAL - IDRC, National Innovation Surveys in Latin America: Empirical Evidence and Policy Implications, CEPAL, Santiago de Chile.

Bishop, K., D'Este, P. and Neely, A. (2011), "Gaining from interactions with universities: Multiple methods for nurturing absorptive capacity", Research Policy, Vol. 40 No.1, pp. 30-40. 
Bogers, M. (2012), "Knowledge sharing in open innovation: an overview of theoretical perspectives on collaborative innovation", SSRN Scholarly Paper ID 1862536.

Bogers, M., Foss, N. and Lyngsie, J. (2018), “The 'human side' of open innovation: the role of employee diversity in firm-level openness", Research Policy, Vol. 47 No. 1, pp. 218-231.

Brenes, E., Montoya, D. and Ciravegna, L. (2014), "Differentiation strategies in emerging markets: the case of Latin American agribusinesses", Journal of Business Research, Vol. 67 No. 5, pp. 847-855.

Chaston, I. and Scott, G. (2012), "Entrepreneurship and open innovation in an emerging economy", Management Decision, Vol. 50 No. 7, pp. 1161-1177.

Cheng, C. and Huizingh, E. (2014), "When is open innovation beneficial? The role of strategic orientation", Journal of Product Innovation Management, Vol. 31 No. 6, pp. 1235-1253.

Chesbrough, H. (2003), “The governance and performance of Xerox's technology spinoff companies", Research Policy, Vol. 32 No. 3, pp. 403-421.

Chesbrough, H. (2006), Open Innovation: The New Imperative for Creating and Profiting from Technology, Harvard Business Press. Boston.

Chiaroni, D., Chiesa, V. and Frattini, F. (2011), "The open innovation journey: how firms dynamically implement the emerging innovation management paradigm", Technovation, Vol. 31 No. 1, pp. 34-43.

Christensen, J.F. (2006), "Wither core competency for the large corporation in an open innovation world?" In Vanhaverbeke, W. West, J. and Chesbrough, H. Open Innovation: Researching a New Paradigm, Oxford University Press, Oxford. pp. $35-61$.

Clausen, T. H. (2013), "External knowledge sourcing from innovation cooperation and the role of absorptive capacity: empirical evidence from Norway and Sweden", Technology Analysis \& Strategic Management, Vol. 25 No. 1, pp. 57-70.

Cohen, W.M. (2010), "Fifty years of empirical studies of innovative activity and performance", in Hall, B. and Rosenberg, N. (Eds), Handbook of the Economics of Innovation (Vol. 1), Elsevier , pp. 129-213.

Cohen, W. and Levinthal, D. (1989), "Innovation and learning: the two faces of R \& D", Economic Journal, Vol. 99 No. 397, pp. 569-596.

Criscuolo, P., Laursen, K., Reichstein, T. and Salter, A. (2018), "Winning combinations: search strategies and innovativeness in the UK", Industry and Innovation, Vol. 25 No. 2, pp. 115-143.

Dahlander, L., O’Mahony, S. and Gann, D. (2016), “One foot in, one foot out: how does individuals' external search breadth affect innovation outcomes?" Strategic Management Journal, Vol. 37 No. 2, pp. 280-302.

Das, T. and Teng, B. (2000), “A resource-based theory of strategic alliances”, Journal of Management, Vol. 26 No. 1, pp. 31-61.

De Araújo Burcharth, A., Knudsen, M. and Søndergaard, H. (2014), "Neither invented nor shared here: the impact and management of attitudes for the adoption of open innovation practices", Technovation, Vol. 34 No. 3, pp. 149-161. 
Deming, D. (2017), "The growing importance of social skills in the labor market", Quarterly Journal of Economics, Vol. 132 No. 4, pp. 1593-1640.

Deming, D. and Kahn, L. (2018), "Skill requirements across firms and labor markets: evidence from job postings for professionals", Journal of Labor Economics, Vol. 36 No. S1, pp. S337-S369.

Du Chatenier, E., Verstegen, J., Biemans, H., Mulder, M. and Omta, O. (2010), "Identification of competencies for professionals in open innovation teams", $R \& D$ Management, Vol. 40 No. 3, pp. 271-280.

Ebers, M. and Maurer, I. (2014), “Connections count: How relational embeddedness and relational empowerment foster absorptive capacity", Research Policy, Vol. 43 No. 2, pp. 318-332.

Eisenhardt, K. and Martin, J. (2000) "Dynamic capabilities: what are they?" Strategic Management Journal, Vol. 21 No. 11, pp. 1105-1121.

Faems, D., De Visser, M., Andries, P. and Van Looy, B. (2010) "Technology alliance portfolios and financial performance: value-enhancing and cost-increasing effects of open innovation". Journal of Product Innovation Management, Vol. 27 No. 6, pp. 785-796.

Fawcett, S., Jones, S. and Fawcett, A. (2012), "Supply chain trust: the catalyst for collaborative innovation", Business Horizons, Vol. 55 No. 2, pp. 163-178.

Felin, T. and Zenger, T. (2014), "Closed or open innovation? Problem solving and the governance choice", Research Policy, Vol. 43 No. 5, pp. 914-925.

Ferreras-Méndez, J. L., Newell, S., Fernández-Mesa, A. and Alegre, J. (2015), “Depth and breadth of external knowledge search and performance: The mediating role of absorptive capacity", Industrial Marketing Management, Vol. 47, pp. 86-97.

Freel, M. (2005), "Patterns of innovation and skills in small firms", Technovation, Vol. 25 No. 2, pp. 123-134.

Frey, C. and Osborne, M. A. (2017), "The future of employment: How susceptible are jobs to computerisation?", Technological Forecasting and Social Change, Vol. 114, pp. 254-280.

Gomez-Mejía, L., Balkin, D. and Cardy, R.L. (2004), Managing Human Resources, Prentice Hall, Upper Saddle River, NJ.

Grant, R. (1996), “Toward a knowledge-based theory of the firm”, Strategic Management Journal, Vol. 17, pp. 109-122.

Grazzi, M. and Pietrobelli, C. (2016), Firm Innovation and Productivity in Latin America and the Caribbean, IDB, Palgrave Macmillan, New York.

Greco, M., Grimaldi, M. and Cricelli, L. (2019), Benefits and costs of open innovation: the BeCO framework. Technology Analysis \& Strategic Management, Vol 31 No.1, pp. 53-66.

Grimpe, C. and Sofka, W. (2016), "Complementarities in the search for innovation managing markets and relationships", Research Policy, Vol. 45 No. 10, pp. 20362053.

Hall, L. and Bagchi-Sen, S. (2007), "An analysis of firm-level innovation strategies in the US biotechnology industry”, Technovation, Vol. 27 Nos 1-2, pp. 4-14. 
Hernández-Perlines, F., Moreno-Garcia, J. and Yáñez-Araque, B. (2016), “Using fuzzyset qualitative comparative analysis to develop an absorptive capacity-based view of training", Journal of Business Research, Vol. 69 No. 4, pp. 1510-1515.

Herstad, S., Sandven, T. and Ebersberger, B. (2015), "Recruitment, knowledge integration and modes of innovation", Research Policy, Vol. 44 No. 1, pp. 138153.

Hillebrand, B. and Biemans, W. (2004), "Links between internal and external cooperation in product development: an exploratory study", Journal of Product Innovation Management, Vol. 21 No. 2, pp. 110-122.

Jansen, J., Van Den Bosch, F. and Volberda, H. (2005), "Managing potential and realized absorptive capacity: how do organizational antecedents matter?", Academy of Management Journal, Vol. 48 No. 6, pp. 999-1015.

Katila, R. and Ahuja, G. (2002), "Something old, something new: a longitudinal study of search behavior and new product introduction", Academy of Management Journal, Vol. 45 No. 6, pp. 1183-1194.

Köhler, C., Sofka, W. and Grimpe, C. (2012), "Selective search, sectoral patterns, and the impact on product innovation performance", Research Policy, Vol. 41 No. 8, pp. 1344-1356.

Laker, D. and Powell, J. L. (2011), "The differences between hard and soft skills and their relative impact on training transfer", Human Resource Development Quarterly, Vol. 22 No. 1, pp. 111-122.

Laursen, K and Foss, N. J. (2014), "Human resource management practices and innovation", in: Dodgson, M. Gann, D. and Phillips, N. (Eds.). The Oxford Handbook of Innovation Management, Oxford University Press, Oxford, pp. 506529.

Laursen, K. and Salter, A. (2006), "Open for innovation: the role of openness in explaining innovation performance among UK manufacturing firms", Strategic Management Journal, Vol. 27 No. 2, pp. 131-150.

Laursen, K. and Salter, A. (2014), "The paradox of openness: appropriability, external search and collaboration", Research Policy, Vol. 43 No. 5, pp. 867-878.

Lazzarotti, V., Manzini, R. and Pellegrini, L. (2015), "Is your open-innovation successful? The mediating role of a firm's organizational and social context", International Journal of Human Resource Management, Vol. 26 No. 19, pp. 24532485 .

Leiponen, A. and Helfat, C. (2010), "Innovation objectives, knowledge sources, and the benefits of breadth", Strategic Management Journal, Vol. 31 No. 2, pp. 224-236.

Lichtenthaler, U. and Lichtenthaler, E. (2009), “A capability-based framework for open innovation: complementing absorptive capacity”, Journal of Management Studies, Vol. 46 No. 8, pp. 1315-1338.

Lichtenthaler, U. and Lichtenthaler, E. (2010), "Technology transfer across organizational boundaries: absorptive capacity and desorptive capacity", California Management Review, Vol. 53 No.1, pp. 154-170.

Lindegaard, S. and Kawasaki, G. (2010), The Open Innovation Revolution: Essentials, Roadblocks and Leadership Skills, Wiley, London. 
Lippitz, V., Thedieck, B. and Jost, S. (2017), "The human side of open innovation: traits, abilities and motivational factors to successfully manage open innovation projects", in Salampasis, D. and Mention, A. (Eds), Open Innovation: Unveiling the Power of the Human Element, World Scientific Publishing Co. Pte. Ltd, pp. 83-110.

Mairesse, J. and Mohnen, P. (2010), "Using innovation surveys for econometric analysis", in Hall, B. and Rosenberg, N. (Eds), Handbook of the Economics of Innovation (Vol. 2), Elsevier, pp. 1129-1155.

Maltz, E. and Kohli, A. (2000), "Reducing marketing's conflict with other functions: the differential effects of integrating mechanisms", Journal of the Academy of Marketing Science, Vol. 28 No. 4, p. 479.

Michelino, F., Caputo, M., Cammarano, A. and Lamberti, E. (2014), "Inbound and outbound open innovation: organization and performances", Journal of Technology Management \& Innovation, Vol 9 No. 3, pp. 65-82.

Ngang, T. K., Yunus, H. and Hashim, N. H. (2015), "Soft skills integration in teaching professional training: Novice teachers' perspectives", Procedia - Social and Behavioral Sciences, Vol. 186, pp. 835-840.

Nooteboom, B. Van Haverbeke, W. Duysters, G. Gilsing, V. and Van den Oord, A. (2007). "Optimal cognitive distance and absorptive capacity". Research Policy, Vol 36 No 7, pp. 1016-1034.

Ocasio, W. (1997). Towards an attention-based view of the firm. Strategic Management Journal, Vol 18 S1, pp. 187-206.

Organisation for Economic Cooporation and Development (OECD) (2005), Oslo Manual - Guidelines for Collecting and Interpreting Innovation Data, 3rd ed., OECD, Paris.

Pemartín, M., Rodríguez-Escudero, A. and Munuera-Alemán, J. (2018), "Effects of collaborative communication on NPD collaboration results: two routes of influence", Journal of Product Innovation Management, Vol. 35 No. 2, pp. 184 208.

Petroni, G., Venturini, K. and Verbano, C. (2012), "Open innovation and new issues in R\&D organization and personnel management", International Journal of Human Resource Management, Vol. 23 No. 1, pp. 147-173.

Podmetina, D., Volchek, D., Dąbrowska, J. and Fiegenbaum, I. (2013). Human resource practices and open innovation. International Journal of Innovation Management, Vol. 17 No. 6, p. 1340019.

Ramos, J., Otero, J., Arrieta, A. and Vélez, L. (2018), "Determinantes del grado de apertura de las PYMES agroindustriales: una aplicación para el Departamento del Atlántico", Desarrollo y Sociedad, Vol. 80, pp. 189-228.

Remneland-Wikhamn, B. and Knights, D. (2012), "Transaction cost economics and open innovation: implications for theory and practice", Creativity and Innovation Management, Vol. 21 No. 3, pp. 277-289.

Rodrigues, L., Maccari, E. and Campanario, M. (2010), "Expanding the open innovation concept: the case of TOTVS S / A. JISTEM", Journal of Information Systems and Technology Management, Vol. 7 No. 3, pp. 737-754. 
Salge, T., Farchi, T., Barrett, M. I. and Dopson, S. (2013), "When does search openness really matter? A contingency study of health-care innovation projects", Journal of Product Innovation Management, Vol. 30 No. 4, pp. 659-676.

Sofka, W. and Grimpe, C. (2010), "Specialized search and innovation performance evidence across Europe", R\&D Management, Vol. 40 No. 3, pp. 310-323.

Sousa, M. and Rocha, A. (2019), "Skills for disruptive digital business", Journal of Business Research, Vol. 94, pp. 257-263.

Stanko, M., Fisher, G. and Bogers, M. (2017), "Under the wide umbrella of open innovation", Journal of Product Innovation Management, Vol. 34 No. 4, pp. 543558.

Stuermer, M., Spaeth, S. and Von Krogh, G. (2009), "Extending private-collective innovation: a case study” $R \& D$ Management, Vol. 39 No. 2, pp. 170-191.

Ter Wal, A., Criscuolo, P. and Salter, A. (2017), "Making a marriage of materials: the role of gatekeepers and shepherds in the absorption of external knowledge and innovation performance”, Research Policy, Vol. 46 No. 5, pp. 1039-1054.

Tether, B., Mina, A., Consoli, D. and Gagliardi, D. (2005), A Literature Review on Skills and Innovation. How Does Successful Innovation Impact on the Demand for Skills and How Do Skills Drive Innovation? ESRC Centre for Research on Innovation and Competition, University of Manchester, Manchester.

Vanhaverbeke, W., Chesbrough, H. and West, J. (2014), "Surfing the new wave of open innovation research", in Vanhaverbeke, W., Chesbrough, H. and West, J. (Eds), New Frontiers in Open Innovation, Oxford University Press, Oxford, pp. 281-294.

Vanhaverbeke, W., van de Vrande, V. and Cloodt, M. (2008), "Connecting absorptive capacity and open innovation”, available at: https://doi.org/10.2139/ssrn.1091265

Vega-Jurado, J., Gutiérrez-Gracia, A. and Fernández-de-Lucio, I. (2008) “Analyzing the determinants of firm's absorptive capacity: beyond R\&D”, $R \& D$ Management, Vol. 38 No.4, pp. 392-405

Villena, V., Revilla, E. and Choi, T. (2011), "The dark side of buyer-supplier relationships: a social capital perspective", Journal of Operations Management, Vol. 29 No. 6, pp. 561-576.

West, J. and Bogers, M. (2014), "Leveraging external sources of innovation: a review of research on open innovation", Journal of Product Innovation Management, Vol. 31 No. 4, pp. 814-831.

West, J., Salter, A., Vanhaverbeke, W. and Chesbrough, H. (2014), “Open Innovation: The Next Decade", Research Policy Vol. 43 No 5, pp. 805-811.

Williamson, O. (1981), "The economics of organization: the transaction cost approach", American Journal of Sociology, Vol. 87 No. 3, pp. 548-577.

Zahra, S.A. and George, G. (2002), "Absorptive capacity: a review, reconceptualization, and extension", Academy of Management Review, Vol. 27 No. 2, pp. 185-203. 
Table 1. Structure of the panel

\begin{tabular}{|ccc|r|r|r|}
\multicolumn{3}{|c|}{ UIS Wave } & & & \\
\hline 2006 & $\mathbf{2 0 0 9}$ & $\mathbf{2 0 1 2}$ & \multicolumn{1}{|c|}{ N } & \multicolumn{1}{c|}{$\%$} & \% Cum. \\
\hline X & X & X & 196 & 13.37 & 13.37 \\
& X & X & 183 & 12.48 & 25.85 \\
X & X & & 114 & 7.78 & 33.63 \\
X & & X & 50 & 3.41 & 37.04 \\
& & $X$ & 216 & 14.73 & 51.77 \\
& X & & 324 & 22.10 & 73.87 \\
X & & & 383 & 26.13 & 100
\end{tabular}

Table 2. Dependent Variables: descriptive statistics

\begin{tabular}{lcr|rrrr} 
& \multicolumn{2}{c|}{ Technical Skills } & \multicolumn{4}{c}{ Social Skills } \\
& \multicolumn{2}{c}{ Qualifications } & \multicolumn{2}{c}{$\begin{array}{c}\text { Cooperation and } \\
\text { communication }\end{array}$} & \multicolumn{2}{c}{ Adaptation } \\
\hline Increased & 986 & 44.72 & 806 & 36.55 & 758 & 34.58 \\
Constant & 1,156 & 52.43 & 1,353 & 61.36 & 1,404 & 63.67 \\
Decreased & 62 & 2.81 & 46 & 2.09 & 43 & 1.95 \\
Total & 2,204 & 100 & 2,205 & 100 & 2,205 & 100 \\
\hline
\end{tabular}


Table 3 - Frequency of Openness Strategies

\begin{tabular}{|c|c|c|c|c|}
\hline \multirow[b]{2}{*}{ Combinations } & \multicolumn{2}{|c|}{ Low Intensity } & \multicolumn{2}{|c|}{ High Intensity } \\
\hline & $\mathrm{N}$ & $\%$ & $\mathrm{~N}$ & $\%$ \\
\hline No external sources & 82 & 3.72 & 725 & 32.88 \\
\hline Suppliers only & 36 & 1.63 & 95 & 4.31 \\
\hline Universities only & 42 & 1.90 & 179 & 8.12 \\
\hline Customers only & 25 & 1.13 & 228 & 10.34 \\
\hline Competitors only & 11 & 0.50 & 41 & 1.86 \\
\hline Fairs only & 27 & 1.22 & 157 & 7.12 \\
\hline Suppliers and universities & 24 & 1.09 & 34 & 1.54 \\
\hline Suppliers and customers & 45 & 2.04 & 90 & 4.08 \\
\hline Suppliers and competitors & 5 & 0.23 & 9 & 0.41 \\
\hline Suppliers and fairs & 34 & 1.54 & 38 & 1.72 \\
\hline Universities and customers & 28 & 1.27 & 69 & 3.13 \\
\hline Universities and competitors & 6 & 0.27 & 11 & 0.50 \\
\hline Universities and fairs & 44 & 2.00 & 85 & 3.85 \\
\hline Customers and competitors & 14 & 0.63 & 58 & 2.63 \\
\hline Customers and fairs & 33 & 1.50 & 51 & 2.31 \\
\hline Competitors and fairs & 11 & 0.50 & 7 & 0.32 \\
\hline Suppliers, universities and customers & 54 & 2.45 & 32 & 1.45 \\
\hline Suppliers, universities and competitors & 4 & 0.18 & 2 & 0.09 \\
\hline Suppliers, universities and fairs & 64 & 2.90 & 21 & 0.95 \\
\hline Suppliers, customers and competitors & 53 & 2.40 & 40 & 1.81 \\
\hline Suppliers, customers and fairs & 56 & 2.54 & 25 & 1.13 \\
\hline Suppliers, competitors and fairs & 9 & 0.41 & 7 & 0.32 \\
\hline Universities, customers and competitors & 25 & 1.13 & 15 & 0.68 \\
\hline Universities, customers and fairs & 41 & 1.86 & 37 & 1.68 \\
\hline Universities, competitors and fairs & 19 & 0.86 & 8 & 0.36 \\
\hline Customers, competitors and fairs & 24 & 1.09 & 21 & 0.95 \\
\hline Suppliers, universities, customers and competitors & 76 & 3.45 & 14 & 0.63 \\
\hline Suppliers, universities, customers and fairs & 193 & 8.75 & 24 & 1.09 \\
\hline Suppliers, universities, competitors and fairs & 28 & 1.27 & 5 & 0.23 \\
\hline Suppliers, customers, competitors and fairs & 103 & 4.67 & 21 & 0.95 \\
\hline Universities, customers, competitors and fairs & 87 & 3.95 & 30 & 1.36 \\
\hline All sources & 902 & 40.91 & 26 & 1.18 \\
\hline No sources & 82 & 3,72 & 725 & 32,88 \\
\hline One source & 141 & 6,39 & 700 & 31,75 \\
\hline Two sources & 244 & 11,07 & 452 & 20,50 \\
\hline Three sources & 349 & 15,83 & 208 & 9,43 \\
\hline Four sources & 487 & 22,09 & 94 & 4,26 \\
\hline All sources & 902 & 40,91 & 26 & 1,18 \\
\hline
\end{tabular}


Table 4 - Control Variables. Descriptive Statistics

\begin{tabular}{llrr}
\hline & & \multicolumn{2}{c}{ Total Sample } \\
\hline & Variable & Mean & Std Err. \\
\hline (1) & \% Export & 15.71 & 30.11 \\
(2) & Firm size (ln) & 4.19 & 1.36 \\
(3) & Age (ln) & 2.94 & 0.93 \\
(4) & Foreign direct investment (D) & 0.17 & 0.38 \\
(5) & Part of a group (D) & 0.22 & 0.41 \\
(6) & Financial obstacles (D) & 0.37 & 0.48 \\
(7) & Shortage of qualified personnel (D) & 0.49 & 0.49 \\
(8) & Government support (D) & 0.12 & 0.33 \\
(9) & Human capital stock (ST professionals/employees) & 12.19 & 15.86 \\
(10) & Manufacturing industry (D) & 0.50 & 0.50 \\
(11) & Uses internal sources (D) & 0.92 & 0.29 \\
\hline
\end{tabular}

(1) Variable that indicates the percentage of firm's total sales corresponding to export; (2) number of employees of the firm (ln); (3) difference between the date when the firm initiated its activities and the year of the survey (logs); (4) dummy variable that indicates whether the firm declares a positive percentage of foreign capital; (5) dummy variable that indicates whether the firm belongs to an economic group; (6) dummy variable that indicates whether the firm experienced financial obstacles to innovation; (7) dummy variable that indicates whether the firm experienced obstacles to innovation because of shortages of qualified personnel; (8) dummy variable that indicates whether the firm received any public funding; (9) professionals/employees; (10) dummy variable that indicates whether the firm belongs to the manufacturing sector; and (11) dummy variable that indicates whether the firm declared that it used internal sources of information.

Source: Developed by the authors based on the UIS database. 
Table 5. Openness Breadth and Depth. Binomial Logit. Dependent Variable: Increasing Recruitment Needs

\begin{tabular}{|c|c|c|c|c|}
\hline & \multirow{2}{*}{\multicolumn{2}{|c|}{ Baseline }} & \multirow{2}{*}{\multicolumn{2}{|c|}{ Breadth and Depth }} \\
\hline & & & & \\
\hline & $\begin{array}{c}\text { Technical skills } \\
\text { (1) }\end{array}$ & $\begin{array}{c}\text { Social skills } \\
(2)\end{array}$ & $\begin{array}{c}\text { Technical skills } \\
\text { (3) }\end{array}$ & $\begin{array}{c}\text { Social skills } \\
\text { (4) }\end{array}$ \\
\hline \multirow[t]{2}{*}{ \% Export } & -0.00111 & -0.00255 & -0.00153 & -0.00280 \\
\hline & $(30.11)$ & $(30.10)$ & $(30.11)$ & $(30.10)$ \\
\hline \multirow[t]{2}{*}{ Size $(\ln )$} & $0.126^{* * *}$ & -0.000241 & $0.127 * * *$ & -0.00172 \\
\hline & $(1.362)$ & $(1.362)$ & $(1.362)$ & $(1.362)$ \\
\hline \multirow[t]{2}{*}{ Age $(\ln )$} & 0.00947 & $-0.107^{*}$ & 0.0147 & $-0.104 *$ \\
\hline & $(0.936)$ & $(0.936)$ & $(0.936)$ & $(0.936)$ \\
\hline \multirow[t]{2}{*}{ Foreign direct investment (D) } & $0.235^{*}$ & $0.245^{*}$ & $0.242 *$ & $0.247^{*}$ \\
\hline & $(0.377)$ & $(0.377)$ & $(0.377)$ & $(0.377)$ \\
\hline \multirow[t]{2}{*}{ Part of a group (D) } & 0.00866 & 0.215 & 0.00873 & $0.217^{*}$ \\
\hline & $(0.413)$ & $(0.412)$ & $(0.413)$ & $(0.412)$ \\
\hline \multirow[t]{2}{*}{ Financial obstacles (D) } & -0.153 & -0.0823 & $-0.208^{* *}$ & -0.123 \\
\hline & $(0.483)$ & $(0.483)$ & $(0.483)$ & $(0.483)$ \\
\hline \multirow[t]{2}{*}{ Shortage of qualified personnel (D) } & $0.390 * * *$ & $0.399 * * *$ & $0.307 * * *$ & $0.334 * * *$ \\
\hline & $(0.500)$ & $(0.500)$ & $(0.500)$ & $(0.500)$ \\
\hline \multirow[t]{2}{*}{ Government support (D) } & $0.242^{*}$ & 0.0614 & 0.191 & 0.0196 \\
\hline & $(0.330)$ & $(0.330)$ & $(0.330)$ & $(0.330)$ \\
\hline \multirow[t]{2}{*}{ Human capital stock (ST professionals/employees) } & $0.00516^{*}$ & -0.000484 & 0.00464 & -0.000874 \\
\hline & $(15.89)$ & $(15.90)$ & $(15.89)$ & $(15.90)$ \\
\hline \multirow[t]{2}{*}{ Manufacturing industry (D) } & $-0.234 * *$ & $-0.410^{* * *}$ & $-0.234 * *$ & $-0.407^{* * *}$ \\
\hline & $(0.500)$ & $(0.500)$ & $(0.500)$ & $(0.500)$ \\
\hline \multirow[t]{2}{*}{ Uses internal sources (D) } & $0.591 * * *$ & $0.517 * *$ & $0.357^{*}$ & 0.348 \\
\hline & $(0.268)$ & $(0.268)$ & $(0.268)$ & $(0.268)$ \\
\hline \multirow[t]{2}{*}{ Year $=2009$} & $-0.193^{*}$ & -0.0946 & $-0.176^{*}$ & -0.0797 \\
\hline & $(0.484)$ & $(0.484)$ & $(0.484)$ & $(0.484)$ \\
\hline \multirow[t]{2}{*}{ Year $=2012$} & $-0.617 * * *$ & $-0.341 * * *$ & $-0.596 * * *$ & $-0.319^{* *}$ \\
\hline & $(0.456)$ & $(0.456)$ & $(0.456)$ & $(0.456)$ \\
\hline \multirow[t]{2}{*}{ Depth } & & & $0.182 * * *$ & $0.137 * * *$ \\
\hline & & & $(1.195)$ & $(1.195)$ \\
\hline \multirow[t]{2}{*}{ Breadth } & & & $0.110^{* * *}$ & $0.0757^{*}$ \\
\hline & & & $(1.438)$ & $(1.438)$ \\
\hline Constant & $-1.202 * * *$ & $-1.037 * * *$ & $-1.575^{* * *}$ & $-1.298 * * *$ \\
\hline Log pseudolikelihood & -1455.3653 & -1254.6249 & -1432.3864 & -1244.3889 \\
\hline Observations & 2,190 & 2,191 & 2,190 & 2,191 \\
\hline
\end{tabular}

\footnotetext{
$* * * \mathrm{p}<0.01, * * \mathrm{p}<0.05, * \mathrm{p}<0.1$
} 
Table 6. Openness Strategies. Dependent Variable: Increasing Recruitment Needs

\begin{tabular}{|c|c|c|c|c|}
\hline & \multicolumn{2}{|c|}{ Low Intensity } & \multicolumn{2}{|c|}{ High Intensity } \\
\hline & $\begin{array}{c}\text { Technical skills } \\
\text { (1) }\end{array}$ & $\begin{array}{l}\text { Social skills } \\
\text { (2) }\end{array}$ & $\begin{array}{l}\text { Technical skills } \\
\text { (3) }\end{array}$ & $\begin{array}{c}\text { Social skills } \\
\text { (4) }\end{array}$ \\
\hline Export \% & -0.00150 & -0.00299 & -0.00145 & -0.00280 \\
\hline Log firm size & $0.119 * * *$ & -0.00316 & $0.113 * * *$ & -0.00647 \\
\hline Age & -0.00281 & $-0.128 * *$ & 0.0247 & $-0.105^{*}$ \\
\hline Foreign direct investment (D) & 0.207 & $0.250 *$ & $0.250^{*}$ & $0.268 *$ \\
\hline Part of a group (D) & 0.00620 & 0.211 & 0.0446 & $0.253^{*}$ \\
\hline Financial obstacles (D) & $-0.194 * *$ & -0.131 & $-0.214 * *$ & -0.108 \\
\hline Shortage of qualified personnel (D) & $0.355^{* * *}$ & $0.380^{* * *}$ & $0.358^{* * *}$ & $0.374 * * *$ \\
\hline Government support (D) & 0.200 & 0.0278 & 0.183 & 0.0312 \\
\hline Human capital stock & 0.00333 & -0.000802 & 0.00374 & -0.00122 \\
\hline Manufacturing industry (D) & $-0.227 * *$ & $-0.404 * * *$ & $-0.251 * *$ & $-0.425 * * *$ \\
\hline Uses internal sources (D) & $0.340 *$ & $0.393 *$ & $0.499 * * *$ & $0.420 * *$ \\
\hline Year $=2009$ & -0.175 & -0.109 & -0.161 & -0.0516 \\
\hline Year $=2012$ & $-0.577 * * *$ & $-0.335 * *$ & $-0.600 * * *$ & $-0.304 * *$ \\
\hline Suppliers only & $\begin{array}{c}-0.251 \\
(0.474)\end{array}$ & $\begin{array}{c}-0.00112 \\
(0.484)\end{array}$ & $\begin{array}{c}0.110 \\
(0.228)\end{array}$ & $\begin{array}{c}0.299 \\
(0.251)\end{array}$ \\
\hline \multirow[t]{2}{*}{ Universities only } & 0.577 & $-1.016^{*}$ & $0.519^{* * *}$ & 0.0645 \\
\hline & $(0.421)$ & $(0.614)$ & $(0.171)$ & $(0.199)$ \\
\hline \multirow[t]{2}{*}{ Customers only } & 0.207 & -0.981 & 0.0869 & 0.0235 \\
\hline & $(0.500)$ & $(0.673)$ & $(0.161)$ & $(0.176)$ \\
\hline \multirow[t]{2}{*}{ Competitors only } & 0.0228 & -1.105 & -0.179 & 0.129 \\
\hline & $(0.673)$ & $(1.082)$ & $(0.357)$ & $(0.377)$ \\
\hline \multirow[t]{2}{*}{ Fairs only } & -0.107 & -0.0309 & 0.176 & 0.231 \\
\hline & $(0.537)$ & $(0.566)$ & $(0.186)$ & $(0.205)$ \\
\hline Suppliers and universities & $\begin{array}{c}0.340 \\
(0.536)\end{array}$ & $\begin{array}{c}0.505 \\
(0.537)\end{array}$ & $\begin{array}{l}0.613^{*} \\
(0.372)\end{array}$ & $\begin{array}{c}0.554 \\
(0.376)\end{array}$ \\
\hline \multirow{2}{*}{ Suppliers and customers } & 0.0502 & -0.663 & $0.382 *$ & $0.590^{* *}$ \\
\hline & $(0.452)$ & $(0.529)$ & $(0.228)$ & $(0.244)$ \\
\hline Suppliers and competitors & 0.256 & - & -0.0510 & 0.551 \\
\hline & $(0.902)$ & & $(0.780)$ & $(0.726)$ \\
\hline Suppliers and fairs & 0.137 & 0.0957 & $0.730 * *$ & 0.445 \\
\hline & $(0.477)$ & $(0.511)$ & $(0.339)$ & $(0.367)$ \\
\hline Universities and customers & $0.780^{*}$ & 0.533 & $1.115^{* * *}$ & $0.990 * * *$ \\
\hline & $(0.458)$ & $(0.483)$ & $(0.267)$ & $(0.269)$ \\
\hline Universities and competitors & $1.659^{*}$ & - & 0.909 & 0.937 \\
\hline & $(0.890)$ & & $(0.656)$ & $(0.683)$ \\
\hline Universities and fairs & 0.574 & -0.236 & $0.520^{* *}$ & 0.211 \\
\hline & $(0.407)$ & $(0.481)$ & $(0.245)$ & $(0.275)$ \\
\hline Customers and competitors & $\begin{array}{c}0.760 \\
(0.573)\end{array}$ & $\begin{array}{c}0.582 \\
(0.667)\end{array}$ & $\begin{array}{c}0.174 \\
(0.275)\end{array}$ & $\begin{array}{l}-0.230 \\
(0.359)\end{array}$ \\
\hline Customers and fairs & 0.103 & -0.515 & $0.543 *$ & 0.00335 \\
\hline & $(0.463)$ & $(0.576)$ & $(0.306)$ & $(0.361)$ \\
\hline Competitors and fairs & -0.0693 & -0.389 & 0.488 & -0.316 \\
\hline & $(0.756)$ & $(0.842)$ & $(0.809)$ & $(1.101)$ \\
\hline Suppliers, universities and customers & $\begin{array}{c}0.799^{* *} \\
(0.389)\end{array}$ & $\begin{array}{c}0.431 \\
(0.415)\end{array}$ & $\begin{array}{c}0.812 * * \\
(0.370)\end{array}$ & $\begin{array}{c}0.790^{* *} \\
(0.392)\end{array}$ \\
\hline Suppliers, universities and competitors & $\begin{array}{l}-0.130 \\
(1.280)\end{array}$ & - & $\begin{array}{c}0.292 \\
(1.314)\end{array}$ & - \\
\hline Suppliers, universities and fairs & $0.790^{* *}$ & 0.225 & 0.653 & 0.0472 \\
\hline & $(0.375)$ & $(0.412)$ & $(0.457)$ & $(0.532)$ \\
\hline Suppliers, customers and competitors & $0.681^{*}$ & 0.308 & 0.363 & -0.110 \\
\hline & $(0.381)$ & $(0.425)$ & $(0.335)$ & $(0.367)$ \\
\hline Suppliers, customers and fairs & -0.0737 & 0.547 & 0.131 & 0.388 \\
\hline & $(0.402)$ & $(0.397)$ & $(0.428)$ & $(0.433)$ \\
\hline Suppliers, competitors and fairs & -0.789 & 0.200 & 0.779 & $1.425^{* *}$ \\
\hline & $(1.089)$ & $(0.842)$ & $(0.700)$ & $(0.680)$ \\
\hline Universities, customers and competitors & 0.425 & 0.272 & 0.190 & 0.395 \\
\hline & $(0.489)$ & $(0.521)$ & $(0.562)$ & $(0.625)$ \\
\hline Universities, customers and fairs & 0.548 & 0.0475 & $0.768^{* *}$ & $0.775^{* *}$ \\
\hline & $(0.423)$ & $(0.462)$ & $(0.357)$ & $(0.354)$ \\
\hline Universities, competitors and fairs & $1.219^{* *}$ & -0.0890 & $\begin{array}{c}0.419 \\
(0.748)\end{array}$ & $1.230^{*}$ \\
\hline Customers, competitors and fairs & $\begin{array}{c}(0.533) \\
0.484\end{array}$ & $\begin{array}{c}(0.041) \\
0.555\end{array}$ & $\begin{array}{c}(0 . / 40) \\
0.420\end{array}$ & 0.514 \\
\hline & $(0.534)$ & $(0.525)$ & $(0.440)$ & $(0.438)$ \\
\hline Suppliers, universities, customers and competitors & 0.184 & -0.354 & $1.696^{* * *}$ & 0.792 \\
\hline & $(0.360)$ & $(0.403)$ & $(0.637)$ & $(0.538)$ \\
\hline Suppliers, universities, customers and fairs & $0.984 * * *$ & 0.0839 & $1.375^{* * *}$ & $0.976^{* *}$ \\
\hline & $(0.307)$ & $(0.334)$ & $(0.462)$ & $(0.423)$ \\
\hline Suppliers, universities, competitors and fairs & 0.0205 & -0.427 & 0.990 & 0.874 \\
\hline & $(0.497)$ & $(0.562)$ & $(0.921)$ & $(1.015)$ \\
\hline Suppliers, customers, competitors and fairs & $0.602 *$ & -0.149 & -0.0323 & -0.135 \\
\hline & $(0.333)$ & $(0.370)$ & $(0.439)$ & $(0.563)$ \\
\hline Universities, customers, competitors and fairs & $1.122 * * *$ & 0.202 & $1.465 * * *$ & $0.984 * *$ \\
\hline & $(0.344)$ & $(0.371)$ & $(0.406)$ & $(0.385)$ \\
\hline All sources & $\begin{array}{c}0.857 * * * \\
(0.276)\end{array}$ & $\begin{array}{c}0.337 \\
(0.297) \\
\end{array}$ & $\begin{array}{c}0.964 * * \\
(0.436)\end{array}$ & $\begin{array}{c}0.301 \\
(0.443)\end{array}$ \\
\hline Constant & $-1.516^{* * *}$ & $-0.955^{* *}$ & $-1.347 * * *$ & $-1.138 * * *$ \\
\hline Log pseudolikelihood & -1424.647 & -1229.519 & -1422.298 & -1229.380 \\
\hline Observations & 2,190 & 2,176 & 2,190 & 2,189 \\
\hline
\end{tabular}


Table 7. Openness Strategies. Marginal Effects

\begin{tabular}{|c|c|}
\hline \multicolumn{2}{|c|}{ Openness strategies Low Intensity } \\
\hline & Technical skills \\
\hline Universities and customers & $0.192 *$ \\
\hline Universities and competitors & $0.409^{*}$ \\
\hline Suppliers, universities and customers & $0.197 * *$ \\
\hline Suppliers, universities and fairs & $0.195 * *$ \\
\hline Suppliers, customers and competitors & $0.168^{*}$ \\
\hline Universities, competitors and fairs & $0.301 * *$ \\
\hline Suppliers, universities, customers and fairs & $0.243^{* * *}$ \\
\hline Suppliers, customers, competitors and fairs & $0.149^{*}$ \\
\hline Universities, customers, competitors and fairs & $0.277 * * *$ \\
\hline \multirow[t]{2}{*}{ All sources } & $0.211^{* * *}$ \\
\hline & Social Skills \\
\hline Universities only (-) & $-0.198^{*}$ \\
\hline \multicolumn{2}{|c|}{ Openness strategies High Intensity } \\
\hline & Technical skills \\
\hline Universities only & $0.128 * * *$ \\
\hline Suppliers and universities & $0.151^{*}$ \\
\hline Suppliers and customers & $0.0945^{*}$ \\
\hline Suppliers and fairs & $0.180 * *$ \\
\hline Universities and customers & $0.275^{* * *}$ \\
\hline Universities and fairs & $0.128 * *$ \\
\hline Customers and fairs & $0.134^{*}$ \\
\hline Suppliers, universities and customers & $0.201 * *$ \\
\hline Universities, customers and fairs & $0.190 * *$ \\
\hline Suppliers, universities, customers and competitors & $0.419 * * *$ \\
\hline Suppliers, universities, customers and fairs & $0.340 * * *$ \\
\hline Universities, customers, competitors and fairs & $0.362 * * *$ \\
\hline \multirow[t]{2}{*}{ All sources } & $0.238 * *$ \\
\hline & Social Skills \\
\hline Suppliers and customers & $0.115 * *$ \\
\hline Universities and customers & $0.192 * * *$ \\
\hline Suppliers, universities and customers & $0.154 * *$ \\
\hline Suppliers, competitors and fairs & $0.277 * *$ \\
\hline Universities, customers and fairs & $0.151 * *$ \\
\hline Universities, competitors and fairs & $0.239 *$ \\
\hline Suppliers, universities, customers and fairs & $0.190 * *$ \\
\hline Universities, customers, competitors and fairs & $0.191 * *$ \\
\hline
\end{tabular}

